\title{
Charakteristika rodiny a (pře)výchovy $v$ komunistické perspektivě
}

\author{
Martina Pavelková
}

Rodina je základní a nejstálejší společenství lidí. Je považována za základní jednotku $\vee$ každém politickém systému. $\vee$ průběhu staletí se stoupenci různých filosofických názorů shodovali na hlavním významu rodiny jakožło základu politického uspořádání. Rozdílné však byly charakteristiky této základní instituce, takže pojem rodiny zastřešoval různé formy společenských uskupení.' Nejčastěji základní rodinnou strukturu tvoří tzv. nukleární rodina, tj. rodina složená z rodičů a jejich dětí. Platí, že rodina je prvním modelem společnosti, se kterým se dítě setkává. Prostředí, ve kterém dítě vyrưstá, předurčuje jeho další osobnostní vývoj a jeho vztahy k ostatním lidem. V rodině si jedinec osvojuje určité vzorce chování, žebřřček hodnot a sociální dovednosti, bez kterých se $v$ dospělosti neobejde. Rodina tedy plní významnou socializační funkci. Od starověku až po současnost bylo uskutečněno několik pokusư o přesunutí rodičovské péče na jiné osoby nebo skupiny osob či instituce řizené státem, avšak tyto snahy se nikdy neujaly $v$ širokém měřítku. ${ }^{2} Z$ toho je zřejmé, že rodina $v$ totalitárním režimu tvoří jakýsi samostatný ostrưvek a že každý totalitární režim se bude snažit rodinu a rodinné vazby potlačit. $\vee$ naší práci se budeme věnovat tomu, jak byly rodinné vztahy, práva rodiču a dětí chápány v komunistické ideologii, která se snažila vytvořit novou společnost a nového člověka. Ukážeme především, jakou proměnou prošla rodina a vztahy mezi členy rodiny v období komunistického totalitarismu v Sovětském svazu.

\section{Komunistická „nová morálka“" a strukturální hřích}

Abychom mohli mluvit o pojetí rodiny $\mathrm{v}$ době komunismu, musíme nejprve nastínit obecné cíle, které komunismus sledoval. Zároveň je třeba říci, že pojem komunismus lze velmi obtížně definovat. Tzv. ideální komunismus v historii ještě nikdy nenastal. Mohli bychom jej tedy definovat podle představy, jak by to jednou mohlo vypadat. Komunisté jsou přesvědčeni, že jejich představy o budoucnosti se někdy skutečně naplní, a popisují je tak, jako by opravdu byly reálné. Komunismus však nikdy neexistoval v podobě, za kterou se vydával. Proto se někdy místo o komunismu také mluví o reálném socialismu nebo o stadiu směřování ke komunismu. Cílem komunismu je totální přeměna světa. Snaží se odstranit starý svět a jeho starou morálku a usiluje vybudovat nový, lepší svět s novou morálkou. Cílem komunistické ideologie je zrušení soukromého vlastnictví a reforma rodinného uspořádání. Tím ovšem dochází ke zničení svobody jakožto základního lidského práva. ${ }^{3}$ Nejzákeřnější na komunismu je to, že zločin vydává za dobro. Slova jako spravedlnost, svoboda, humanita, právo, čest mají v komunistickém slovníku zcela jiný význam než ve slovníku tradičních západních demokracií. Jsou to pouhá homonyma, která stejně znějí, avšak význam mají odlišný. Komunistická výchova je nebezpečná a záludná, protože zlé skutky, kterých se dopouští, vydává za dobré. ${ }^{4}$ Komunistický právní

\footnotetext{
1 Srov. Jack GOODY, Proměny rodiny v evropské historii, Praha: Nakladatelství Lidové noviny, 2006. Dále srov. Oldřich MATOUŠEK, Rodina jako instituce a vztahová sít', Praha: SLON, 2003, s. 20-38.

2 Srov. Oldřich MATOUŠEK, Rodina jako instituce a vztahová sít, s. 9-10.

3 Srov. Alain BESANÇON, Le malheur du siècle. Sur le communisme, le nazisme et l'unicité de la Shoah, Paris: Fayard, 1998 , s. 54-58.

4 Srov. Alain BESANÇON, Le malheur du siècle, s. 63.
} 


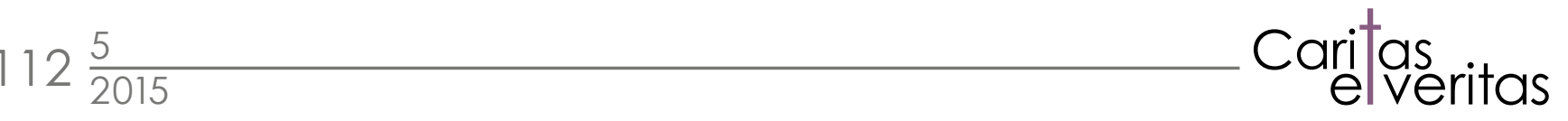

systém je nebezpečný kvůli tomu, že vytváří zákony, které se jakoby snaží uspokojit lidskou touhu po spravedlnosti, avšak ve skutečnosti navozují politickou tyranii. ${ }^{5}$

Komunismus chce vytvořit nového člověka, nový postoj k práci, novou disciplínu, novou morálku. Tato nová morálka je nutná pro budování komunismu. V čem spočívá? Především má praktickou funkci - je nástrojem státu. Nová forma morálky již nespočivá na náboženských nebo tradičních hodnotách. Nová morálka je určována ekonomickými a sociálními podmínkami a vztahy ve společnosti. Mravně špatné a nesprávné návyky nelze podle Marxovy teorie změnit kázáním nebo moralizováním, nýbrž pouze změnou materiálních podmínek společnosti. ${ }^{6}$ Morálka nemá hodnotu sama v sobě, je spíše prostředkem $\mathrm{k}$ dosažení cíle, kterým je vybudování nového světa, dosažení ideálního komunismu, vytvoření beztřídní společnosti.

Vidíme, že toto pojetí morálky je skutečně zcela nové a nemá nic co do činění s dosavadní morálkou západní civilizace, která stojí na křest'anských hodnotách. ${ }^{7}$ Komunismus zcela změnil chápání dobra a zla. Kritériem pro posuzování dobrého jednání již není svědomí jednotlivce. Svědomí v rámci této nové morálky není něco, co by mělo být respektováno, nýbrž má být pouze formováno. Tím, kdo svědomí občanů formuje, je komunistická strana. Jen ona je dárcem a strážcem nové morálky. ${ }^{8}$ Morálka má za úkol posilovat vliv strany v oblastech soukromého života, jako je manželství, rodina a výchova dětí, tedy oblasti, které není možno př́liš regulovat zákony. Morálka se stává formou sociální kontroly a měla by nahradit zákon. ${ }^{9}$ Je žádoucí dosáhnout ideálního stavu, kdy už nebude nutno používat síly k vynucení správného chování, protože občané budou natolik disciplinovaní, že kontrola nad nimi bude jen minimální. ${ }^{10}$ Pokud však je morálka pouze prostředkem sociální kontroly, je zbytečné uvažovat o zdůvodnění mravních soudi̊, etické argumentaci nebo analyzovat pojmy jako vina a dobro. Mravně správné je to, co schválí strana. Když se však strana stává svědomím lidí, nelze jedince považovat za toho, kdo jedná mravně, protože není pánem svých vlastních rozhodnutí. Je zcela zřejmé, že tato nová morálka, komunistický vynález, zcela odporuje přirozenému zákonu.

Je př́íznačné, že vůbec první, kdo poukázal na nebezpečí a zvrácenost komunistické ideologie, nebyl politik nebo ekonom, nýbrž papež Lev XIII. Ještě před bolševickou revolucí, která se pokusila aplikovat marxistickou teorii v praxi, předpověděl, co bude následovat. ${ }^{11}$ Jan Pavel II. o této předpovědi svého předchůdce píše: „Papež Lev XIII. v určitém smyslu předvídal pád komunismu, za nějž lidstvo a Evropa draze zaplatí, protože lék, jak napsal v roce 1891 ve své encyklice, by mohl být nebezpečnější než nemoc! To papež prohlásil s důstojností a autoritou učící církve." ${ }^{12}$ Komunistická ideologie se jakožto ta největší hereze stala terčem kritiky následujících papežů. ${ }^{13}$ Francouzský historik idejí Alain Besançon vidí přímou souvislost mezi

\footnotetext{
5 Srov. Harold J. BERMAN, Soviet Justice and Soviet Tyranny, Columbia Law Review 6/1955, s. 795-807.

6 Srov. Richard T. De GEORGE, R. T. Soviet Ethics and Soviet Society, Studies in East European Thought 4/1964, s. 207.

7 Marxismus-leninismus se snaží dojít jakési spásy srovnatelné s biblickým proroctvím. Chce stvořit nového člověka a novou zemi, dosáhnout míru a spravedlnosti, ve které již nebudou žádné rozpory, a tohoto stavu se snaží dosáhnout politickými prostředky. Avšak to, co je dílem Božím, nemůže být dosaženo lidskými silami. Srov. Alain BESANÇON, Le malheur du siècle, s. 100-101.

8 Srov. Richard T. De GEORGE, Soviet Ethics and Soviet Society, s. 209.

9 Jsou totiž oblasti, kde je užití zákona velmi nepraktické, nebo dokonce nemožné. Takovým př́íkladem je motivace k vyšším výkonům v práci a vyvíjení vlastní iniciativy v rámci kolektivu. Právě zde přichází ke slovu apel na komunistickou novou morálku. Ostatně motivace a pracovní kázeň byla dvě nejvíce diskutovaná témata v komunistické etice. Bylo zapotřebí motivovat dělníky, aby více než na své dobro mysleli na prospěch kolektivu a považovali za svou povinnost zcela se oddat své práci a vážit si jí, at' už je jakákoli. Srov. Richard T. De GEORGE, Soviet Ethics and Soviet Society, s. 211.

10 Tamtéž.

11 Podrobněji srov. Christian WEISSMULLER, Le communisme: un échec annoncé par un pape, Nouvelle revue théologique 6/1995, s. 874-884. 12 JAN PAVEL II., Překročit práh naděje, Praha: Tok, 1995, s. 124.

13 Např. Pius XI. upozorňoval na fakt, že komunistická morálka upírá člověku svobodu a lidskou důstojnost. Komunismus je podle něj nebezpečný právě $v$ tom, že falsifikuje dobro. Své zvrácené názory podává velmi líbivě, čímž zmate mnoho třeba i vzdělaných lidí. Komunismus nepřináší svobodu, nýbrž vrhá lidi do otroctví a usiluje o jejich likvidaci. Divini Redemptoris 8-24.
} 
komunistickou ideologií a strukturálním hříchem. Komunistická ideologie vytváří podle něho strukturální hř́ích těmito kroky ${ }^{14}$ :

1) Popírá, že svět je dobrý, jak shodně tvrdí přirozená náboženství, starověcí filosofové a biblické zjevení.

2) Považuje nenávist za mravní povinnost. „Duch ničení je stejný jako duch tvoření.” (Bakunin)

3) Ruší příkazy přirozené morálky a částečně druhou desku Mojžíšových přikázání. Povinností je zabíjet, krást, lhát - vše podle potřeb třídního boje.

4) Odmítá Boží součinnost s událostmi ve světě, a současně tak popírá každou formu prozřetelnosti. Zodpovědnost je přenesena na Stranu, tj. na skupinu lidí, kteří znají strukturu světa a směr jeho vývoje.

5) Člověk je zbaven svého svobodného úsudku.

Řád společnosti, jak se jej snaží vytvořit komunisté, tedy nutí člověka, aby se podílel na zlu. Toto zlo je však komunisty prezentováno jako dobro. A právě v tomto překrucování či falzifikování dobra spočívá zákeřnost a obludnost komunistické výchovy. ${ }^{15}$

\section{Pojetí člověka a mezilidských vztahů v komunistické ideologii}

Uvedli jsme, že komunisté chtěli spolu s novou morálkou vytvořit nového člověka. Kdo byl tento „nový člověk“? Zodpovězení této otázky je klíčové pro etiku a právo. Zpočátku však nikdo nevěděl, jak by měl tento nový člověk vypadat. ${ }^{16}$ Podle marxistického učení neexistuje žádná neměnná podstata člověka, žádná přirozenost, kterou by člověk měl v minulosti, př́itomnosti a budoucnosti. Marxismus odmítá jak aristotelské pojetí člověka jako „rozumného živočicha“, tak i náboženské pojetí člověka jako jednoty duše a těla. Všechny tyto snahy jsou zavrženy jako metafyzické a jako snahy udělat statické a neměnné $z$ toho, co je ve skutečnosti dynamické, historické, ve vývoji a proměnné. Podle marxismu-leninismu koncept člověka není abstraktní, nýbrž konkrétní, není věčný, nýbrž historický, není metafyzický, nýbrž dialektický. ${ }^{17}$ Marxisticko-leninský koncept člověka vychází z Marxovy teze k Feuerbachovi, podle které je člověk pouze „,souborem společenských vztahü“ ${ }^{18}{ }^{8}$ Biologicky se člověk vyvinul $\mathrm{z}$ opice, avšak v poslední fázi jeho biologického vývoje, kdy nabyl současné fyzické podoby, vstupují do hry také sociální faktory. Od opice se člověk liší schopností pracovat. Prací člověk vytváří sám sebe a prací se také postupně mění. Podle Marxe člověk vytvář́i své vlastní dějiny a v tomto dějinném procesu vytváří sám sebe..$^{19}$ Tím, že člověk svou prací mění vnější svět kolem sebe, mění současně i svou přirozenost. Člověk se vyskytuje jako člověk pouze ve společnosti. Z toho plyne, že člověka nemůžeme nikdy chápat abstraktně, nýbrž vždy jako

14 Srov. Alain BESANÇON, Reconnaître le communisme comme structure de péché, in Joseph RATZINGER, La vérité vous rendra libres. Hommage au Cardinal Georges Cottier, Paris: Parole et Silence, 2004, s. 229.

15 Podrobněji srov. Alain BESANÇON, La falsification du Bien: Soloviev et Orwell, Paris: Julliard, 1985.

16 Sovětský teoretik výchovy Anton Makarenko, který se zabýval otázkou, jak vytvořit „nového člověka“, se ve svém díle Pedagogická poéma vyznává z této rozpačitosti, když píše, že „nového člověka je nutno vytvářet novým způsobem... Ale nikdo neví, jak...“ Anton MAKARENKO, Pedagogická poéma, Praha: SPN, 1976, s. 5.

17 Srov. Richard T. De GEORGE, The Soviet Concept of Man, Studies in East European Thought 4/1964, $261-262$.

18 Karl MARX, Spisy 3, Praha: Státní nakladatelství politické literatury, 1958, s. 18.

19 Srov. Erich FROMM, Obraz člověka u Marxe, Brno: L. Marek, 2004, s. 18. 
konkrétního jedince: Jak se mění vztahy ve společnosti, mění se i přirozenost člověka, který je - jak bylo výše řečeno s odvoláním na Feuerbacha - souborem společenských vztahů. Proto každá epocha utvoří jiné individuum, které má jiné pocity, myšlenky a vnímání. Soubor společenských vztahů zahrnuje například vztahy rodinné, politické, ideologické a právní. Sociální vztahy se však mění velmi pomalu, takže proměna člověka je těžko pozorovatelná. To může vést k mylnému názoru, že lidská přirozenost je věčná a neměnná. ${ }^{20}$

\section{Zničení rodiny jako cesta k nové společnosti - praxe sovětského komunismu}

Proměna chápání člověka se nejvíce promítla do konceptu rodiny. V souladu s komunistickou propagandou měly být děti mnohem méně vázány na své rodiče a rodinné prostředí. Ústřední místo v životě dětí měl zaujímat kolektiv, kde mělo být dítě převychováno a mělo pro sebe získat ten správný ideologický pohled. ${ }^{21}$ Pojem „převýchova“ je jedním z hlavních pojmů komunistické propagandy. Lidská osobnost měla být „opravena“ a nasměrována způsobem, který je žádoucí. ${ }^{22}$ Ze tři hlavních pilírư moderní společnosti - rodina, škola, církev ${ }^{23}$ - měl zbýt jen jeden. Komunisté, kteří chtějí vytvořit nový svět, se snaží eliminovat rodinu a církev, protože tyto svou povahou udržují tradici, pro kterou není v novém společenském uspořádání žádné místo. ${ }^{24}$ Institut školy je zachován, protože může být použit jako nástroj kulturní revoluce. ${ }^{25}$ Rodina je naproti tomu chápána jako místo tmářství a pověr. Zpátečnické matky nejsou schopny vychovávat své děti v souladu s novou ideologií. Výchova dětí mimo rodinu měla dětem napomoci zpřetrhat vazby s minulostí a umožnit jim dýchat ovzduší pokroku. Děti tak budou moci poznávat nový svět, který pro ně komunisté budují. ${ }^{26}$ Velmi skloňovaným pojmem po ř́jnové revoluci se stala důstojnost ženy. Oproti dosavadní patriarchální společnosti měla být žena vymaněna ze závislosti na muži. Za tímto účelem byly zřízeny společné jídelny, šicí dílny, zařízení na hlídání dětí, veřejné prádelny, které měly nahradit neplacené domácí práce žen. Ženy, osvobozené od starosti o domácnost, tak mohly dosáhnout rovnoprávnosti s muži. Postupné vymizení domácích prací bylo chápáno jako nutná fáze dějinného vývoje. Péče o domácnost nemá žádné místo v novém světě, který vznikne socialistickou transformací.

Krátce poté, co se bolševici v Rusku roku 1917 chopili moci, vydala sovětská vláda množství nových opatření, která měla změnit strukturu a funkci rodiny. Od roku 1917 do roku 1945 bylo vydáno několik výnosů, které upravovaly uzavření manželství, rozvod a vztah rodičů a dětí. ${ }^{27}$ Hned v prvních deseti letech po revoluci nová sovětská vláda předložila tři návrhy, podle nichž se měla rodina proměnit v období přechodu od socialismu ke komunismu. Podle prvního návrhu měla být rodina zrušena a nahrazena kolektivní výchovou dětí ve státem provozovaných institucích a internátech. Zastánci takové myšlenky se odvolávali na to, že eliminace

20 Srov. Richard T. De GEORGE, The Soviet Concept of Man, s. 262-264.

21 V tomto duchu píše Makarenko: „Rodina přestala být otcovou rodinou. Naše žena požívá stejných práv jako muž, naše matka má právo rovnající se právům otce. Naše rodina není podrobena otcově samovládě, nýbrž tvoří sovětský kolektiv." Anton MAKARENKO, O výchově dětí v rodině, Praha: SPN, 1957, s. 15.

22 Srov. Jindřich KABÁT, Psychologie komunismu, Praha: Práh, 2011, s. 402.

23 K těmto třem základním socializačním pilířơm někteří sociologové přidávají v současné době ještě média. Srov. Robert KUBEY, Media Implications for the Quality of Family Life, in: Social Scientific, Psychodynamic, and Clinical Perspectives, ed. Dolf ZILLMANN - Jennings BRYANT - Aletha C. HUSTON, Routledge, 1994, s. 61-69.

24 Komunisté se snaží nahradit Boha a náboženské instituce. Sami si vytvářejí jakési „sekulární náboženství“ a používají náboženské prvky - zbožšt'ují své vůdce, masová setkání jsou považována za posvátné akce. Podle Simone Weilové „není překvapivé, že marxismus měl vždy náboženský charakter. Má mnoho společného právě s těmi formami náboženského života, které Marx nejvíce napadal, zvláště v tom, že je, podle Marxových vlastních slov, opium lidstva. Ale je to náboženství bez mystiky, v pravém smyslu tohoto slova." Srov. Simone WEIL, Oppression et liberte, Paris: Éditions Gallimard, 1955, s. 152.

25 Srov. Nicholas S. TIMASHEFF, The Attempt to Abolish the Family in Russia, Ecologist 4/1974,s. 144.

26 Srov. Elizabeth WATERS, The Bolsheviks and the Family, Contemporary European History 3/1995, s. 280.

27 Srov. Becky L. GLASS - Margaret K. STOLEE, Family Law in Soviet Russia, 1917-1945, Journal of Marriage and Family 4/1987, s. 893-902. 
rodiny je v souladu s marxistickou ideologií. Rodina totiž produkuje nesprávný druh individuí, tj. ty, kteří nejsou schopni přispívat kolektivu, nebot' to jsou sobečtí jedinci. Tento návrh, který počítal s úplným zrušením rodiny, byl živý především v prvním desetiletí po revoluci, avšak v praxi nebyl realizován. Druhý návrh stavěl na domněnce, že není reálné rodinu zcela odstranit a že rodina může plnit svou funkci také v socialismu. Jen je třeba s rodiči intenzivně spolupracovat a školit je tak, aby vychovávali št'astné a zdravé děti. K tomu měly sloužit různé brožurky, konzultační centra a speciální kurzy, které by matkám pomáhaly s výchovou dětí. Třetí návrh předpokládal, že děti samy budou využity jako agenti revolučních myšlenek ve svých vlastních domovech. Děti by za tím účelem byly nejprve školeny ve speciálních institucích a poté by doma poučovaly své rodiče. Měla být podporována přirozená touha dětí po změně a objevování nového, aby se děti po návratu do svých rodin nevrátily ke starému, nežádoucímu zpo̊sobu života. ${ }^{28}$ Někteří autoři nazývají tyto změny v rodinném právu jako ruský experiment vedoucí ke zničení rodiny. ${ }^{29} \mathrm{Na}$ následujících stránkách si ukážeme, jakými konkrétními prostředky bylo komunistických ideálů o rodině dosahováno v sovětském Rusku a jakým vývojem prošlo tamější chápání rodiny.

\subsection{První perioda: 1918-1926}

Okamžitě po získání moci se bolševici snažili distancovat od carské společnosti a co nejvíce eliminovat vliv prerevolučních tradic a zákonů na novou společnost a nové občany, které chtěli bolševici vytvořit. Bylo třeba předložit legislativní základ pro budování komunistické společnosti. Až do roku 1917 byla žena zcela podřizena manželovi, přijala jeho jméno a sdílela jeho sociální status. Bez jeho souhlasu nemohla získat práci nebo vzdělání. Muž měl také kontrolu nad svými dětmi. Za legitimní se považovaly pouze děti narozené v manželství. Ruská ortodoxní církev považovala manželství za svátost a rozvod byl téměř nemožný. Tyto staré zvyklosti měly být upraveny zákonem, který vstoupil v platnost roku 1918. Již předtím však byly vydány dekrety, které značně oslabovaly manželský vztah a činily manželství snadno rozlučitelným. Byly zpřetrhány vazby mezi manželstvím a církví - církevní sňatky neměly žádný právní význam. Místo svatby v kostele bylo třeba registrovat manželství na místním úřadu, který byl za tím účelem zřízen (ZAGS) 30. Při uzavírání manželství nebyli snoubenci poučeni o tom, co manželství ve své podstatě znamená. Ještě větší změny nastaly v případě rozvodu. Zatímco podle dřivějších zákonů bylo velmi obtížné se rozvést, podle nového zákoníku bylo možné rozvést manželství bez udání důvodu. Byla zrušena možnost adopce. ${ }^{31}$ K oslabení tradiční rodiny přispělo i to, že incest, bigamie a smilstvo přestaly být považovány za trestné činy. ${ }^{32}$ Byl povolen potrat i pro případ, kdy neexistovala žádná medicínská indikace. ${ }^{33}$ Potvrdily se tak revoluční vize o sociálních vztazích založených na rovnoprávnosti žen

28 Srov. Becky L. GLASS - Margaret K. STOLEE, Family Law in Soviet Russia, s. 893-894.

29 Srov. napr. Nicholas S. TIMASHEFF, The Attempt to Abolish the Family in Russia, s. 144-148.

30 Zkratka ZAGS znamená „Civilní registrační úřad“. Tyto úřady byly zř́zeny již v prosinci 1917 a bylo nutno zde hlásit události jako uzavření manželství, narození dítěte, rozvod, úmrtí. John Hazard nazývá tyto úřady "prostými strážci rutiny“, protože nikdo nemohl uniknout jejich pozornosti. Doslova „pronásledovaly každý krok člověka od kolébky do hrobu“. Srov. John HAZARD, Humble Guardians of Routines (Notaries and ZAGS), in: Soviet Law After Stalin: Soviet Institutions and the Administration of Law III., ed. Donald D. BARRY, Kluwer Academic Publishers, 1979, s. 245-266.

31 Zrušení adopce někteři pozdější analytikové považovali za jeden z počátečních kroků vedoucích ke zrušení institutu rodiny. John Hazard uvádí tři důvody pro zrušení adopce: 1) sovětští zákonodárci považovali adopci za buržoazní přežitek; 2) předpokládalo se, že děti budou hromadně vychovávány mimo rodinu; 3) zákonodárci chtěli zabránit vznikání nových rodin do té doby, než bude zákonem upravena problematika dědictví. John HAZARD, The Child under Soviet Law, University of Chicago Law Review 5/1938, s. 429-430.

32 Srov. Nicholas S. TIMASHEFF, The Attempt to Abolish the Family in Russia, s. 144.

33 Byly zřízeny komise, které posuzovaly důvody, kvůli kterým ženy žádaly potrat. Nejčastěǰ̌ím ženami udávaným faktorem byla chudoba. Ačkoli zákon potrat umožnil, ženy se stále uchylovaly $\mathrm{k}$ „potratům na černo“, které prováděly především porodní asistentky. Dủvody pro to byly různé - snaha vyhnout se bolesti v nemocnici (při zákroku se nepoužívala anestetika), nedostupnost nemocnic zvláště na venkově, nechut' k vysvětlování před komisí, snaha utajit těhotenství nebo větší důvěra v porodní asistentky než doktory v nemocnicích. Těžko získat přesnou statistiku ilegálních potratů, protože jejich počet můžeme odvozovat pouze z případů žen, které po provedení ilegálního potratu skončily z důvodu zdravotních komplikací v nemocnici. Na venkově byl počet ilegálních potratů dokonce vyšší než legálních potratů. Na 
a eliminaci rodiny. Žena již nepotřebovala povolení od svého manžela, aby mohla pracovat. Autor nového zákoníku prohlásil, že „zákon připravuje dobu, kdy pouta mezi mužem a ženou budou překonána". ${ }^{34}$ Tvůrci tohoto zákoníku si byli vědomi toho, že je pouze přechodný, ${ }^{35}$ a tak volili takové výrazy, které jim umožní připravit zákoník nový. Např. se nemluvilo o mimomanželských dětech, nýbrž o „dětech, které se narodily rodičům, kteří nejsou v registrovaném manželství", aby se tak připravila cesta pro volné, neregistrované svazky. ${ }^{36}$ Rodina jakožto "hrozivá bašta všech nemravností starého režimu“ měla být zničena. ${ }^{37}$ Zákon upravil vztahy mezi manžely, avšak nebylo jasné, co znamená rodina a jakou roli má mít v budoucnosti.

Brzy se začaly objevovat neblahé důsledky tohoto zákona. Snadná dostupnost rozvodu (který měl ženám přinést sociální nezávislost) měla za následek mnoho opuštěných žen a nezaopatřených dětí. Rozvodovost v Sovětském svazu prudce stoupla. Po rozvodu bylo pro ženu velmi těžké se o sebe postarat, protože nezaměstnanost žen byla ve dvacátých letech dvacátého století velmi vysoká. Ekonomická situace v Sovětském svazu ve dvacátých letech neumožnila realizaci všech revolučních změn. Podle komunistické ideologie založené na zrušení soukromého vlastnictví a zániku sociálních tříd měly být vztahy mezi lidmi osvobozeny od ekonomických faktorů. Manželství mezi mužem a ženou mělo být založeno na rovnosti obou pohlaví. Zdálo se, že zrušením vlastnictví bude této rovnosti dosaženo. Ekonomická zaostalost působila neočekávané problémy v uskutečňování komunistického konceptu rodiny. Teoreticky mělo být rovnosti mezi mužem a ženou dosaženo osvobozením ženy od domácích prací. Bezplatné výchovné instituce, kam matky mohly děti umístit, a levné restaurace, kde se členové rodiny mohli stravovat, měly ženě umožnit najít si práci mimo domov a osvobodit se z ekonomické závislosti na muži. Stát však neměl peníze na zřízení bezplatných výchovných institucí pro děti ani na financování dalších zařízení, které měly ženám nahradit domácí práce. Takže kvůli velké nezaměstnanosti, snadné dostupnosti rozvodu a neexistenci bezplatných zařizení pro děti stoupal počet žen, které po rozvodu zůstaly samy s dítětem a bez prostředků. ${ }^{38}$

Nový zákon o rodině začal platit od roku 1926. Oproti roku 1918 došlo k několika změnám. Největší změnou bylo zavedení institutu „neregistrovaného manželství“ , které bylo postaveno na stejnou úroveň jako legálně uzavřené manželství. Neregistrovaným manželstvím (někdy se používá název manželství de facto) se rozumělo každé soužití muže a ženy, pokud byla splněna alespoň jedna z podmínek: 1) trvalé soužití; 2) společné bydlení; 3) přiznání vztahu před třetí osobou; 4) vzájemná podpora a společná výchova dětí. Další zvláštností bylo, že podle zákona musel člověk přijmout jakoukoli práci, která mu byla přidělena. Nezřídka se stalo, že muž a žena dostali práci každý v jiném městě, takže od sebe byli odloučeni. $V$ takovém př́padě jim byl doporučen rozvod s tím, že si jistě najdou nové partnery v místě svého zaměstnání. ${ }^{39}$ Dosáhnout rozvodu bylo ještě snazší než dřive. ${ }^{40}$ Manželství mohlo být dokonce rozvedeno

konci dvacátých let se počet ilegálních potratů významně snížil. Srov. Wendy GOLDMAN, Women, Abortion and the State, 1917-1936, in: Russia's Women: Accommodation, Resistance, Transformation, ed. Barbara CLEMENTS - Barbara ENGEL - Christine WOROBEC, Berkeley: University of California Press, s. 254-260.

34 Wendy Z. GOLDMAN, Women, the State and Revolution: Soviet Family Policy and Social Life, 1917-1936, Cambridge University Press, 1993, s. 1.

35 Zákon sám byl psán s tím, že jednou bude zbytečný. Tvůrce tohoto zákoníku, Alexander Goikhbarg prohlásil: „Síla proletariátu vytváří všechny své zákony dialekticky, takže každým dnem jejich existence se zmenšuje potřeba jejich existence." Stručně řečeno, zákon byl vytvořen proto, aby se stal zbytečným. Goikhbarg a ostatní revolucionáři očekávali nejen to, že se stanou zbytečnými manželství a rodina, ale i zákon a stát. Přesně podle Leninovy stati Stát a revoluce, kterou sepsal měsíc předtím, než se bolševici chopili moci. Srov. Wendy Z. GOLDMAN, Women, the State and Revolution..., s. 1-2.

36 Srov. Wendy Z. GOLDMAN, Women, the State and Revolution..., s. 54-55.

37 Nicholas S. TIMASHEFF, The Attempt to Abolish the Family in Russia, s. 144

38 Srov. Michael D. BERGER, Soviet Divorce Laws and the Role of the Russian Family, Brigham Young University Law Review 3/1986, s. $824-825$.

39 Srov. Nicholas S. TIMASHEFF, The Attempt to Abolish the Family in Russia, s. 145

40 Právník Rostovski, který napsal populární brožurku vykládající rodinné právo, spatřoval v rozvodu „emancipaci jedince obecně, zvláště 
i v případě, že jeden z manželů s rozvodem nesouhlasil. Stačilo, aby se na příslušný úřad dostavil pouze jeden z partnerů, druhý mohl být o rozvodu informován posláním pohledu. ${ }^{41}$ Aby po rozvodu nebyla žena zcela bez finančního zabezpečení, byl zaveden pojem "společné jmění manželư" a rovné dělení tohoto majetku v případě rozvodu. Zákon znovu přesunul odpovědnost na členy rodiny, aby se postarali, především finančně, o ty členy rodiny, kteří nejsou schopni se o sebe starat sami (nezletilé děti, postižení, těhotné ženy a senioři). Místo státní podpory se opět začalo mluvit o tradiční zodpovědnosti rodiny. Nově se upravilo placení výživného v př́padě rozvodu. Podle předchozího zákona z roku 1918 se alimenty platily pouze $\mathrm{v}$ případě, že došlo $\mathrm{k}$ rozvodu manželství, které bylo uzavřeno na úřadě, tedy bylo registrováno. Pokud se rozešel pár, který spolu žil bez registrace manželství, nikomu nevznikla žádná vyživovací povinnost. Podle nového zákoníku z roku 1926 vznikla povinnost platit výživné i v případě rozvodu tzv. neregistrovaného manželství. ${ }^{42}$ Byl zrušen pojem „kolektivní otcovství“. Tento pojem se používal v př́ípadě, kdy otěhotněla neprovdaná žena, která v době početí měla více partnerů. Podle starého zákoníku se na péči o dítě museli podílet všichni partneři rovnoměrně. $\mathrm{V}$ praxi se takový postup ukázal jako nepraktický pro dítě, protože muži měli poskytnout nejen finanční zajištění, ale měli se podílet také na důležitých rodičovských rozhodnutích a aktivně se podílet na výchově dítěte. ${ }^{43}$ Pokud si žena není jistá, který z mužů je otcem jejího dítěte, soud určí jednoho muže, který bude dítě finančně podporovat a podílet se na jeho výchově. Jedním z velkých problému dvacátých let bylo obrovské množství dětí, které se toulaly $\mathrm{v}$ městech a na venkově, protože neměly žádný domov. Byli to tzv. besprizorniki. Stát neměl peníze, aby se o tyto děti staral. ${ }^{44}$ Velmi vzrostla kriminalita mládeže bez domova. Vláda proto znovu povolila adopci, umožnila rodičům, aby se ujali dětí, které neměly domov. Pro adopci platila pravidla: Mohly být adoptovány pouze děti mladší osmnácti let a jen za souhlasu jejich rodičů, pokud tito ještě žili. Pokud dítěti bylo více než deset let, vyžadoval se i jeho souhlas. Rodičům mohlo být dítě odebráno, pokud v rodině nebyly podmínky pro jeho správný vývoj. Adoptované dítě mělo všechna práva a povinnosti jako děti zrozené v manželství, včetně práva dědického. ${ }^{45}$

V oficiální propagandě se neustále opakovalo, že děti jsou povinny poslouchat své rodiče pouze v případě, že rodiče jsou loajální ke straně a disciplinovaně plní stranická nařízení. Rodiče se tedy vystavovali velkému riziku, pokud si dovolili nesouhlasit s marxistickou naukou, včetně militantního ateismu, kterým byly jejich děti indoktrinovány ve škole. Zde se děti učily, jak mají poučovat a převychovávat své rodiče $\mathrm{v}$ duchu komunismu a nahlásit je straně, pokud u nich zpozorují nějaké protikomunistické postoje. ${ }^{46}$ Jasným cílem komunismu tedy bylo přetvořit rodinu podle svého systému, zbavit ji její vlastní autonomie, aby se tak stala místem indoktrinace totalitární ideologie. ${ }^{47}$ Politika rozdělovala rodiny a obracela mladší generaci proti starší. Malé děti, pionýři, se měli stát „očima a ušima strany v rodině“. Od všech dětí

pak emancipaci ženy“. Bylo tedy žádoucí, aby rozvodu bylo dosaženo co nejsnazším způsobem. Citováno podle Wendy Z. GOLDMAN, Freedom and Its Consequences: The Debate on the Soviet Family Code of 1926, Russian History 11/1984, s. 365.

41 Toto období se také nazývá dobou „pohlednicových rozvodů“. Srov. William MOSKOFF, Divorce in the USSR, Journal of Marriage and Family 2/1983, s. 420.

42 Srov. Beatrice B. FARNSWORTH, Bolshevik Alternatives and the Soviet Family. The 1926 Marriage Law Debate, in: Women in Russia, ed. Dorothy ATKINSON - Alexander DALLIN - Gail W. LAPIDUS, Sussex: Harvester Press, 1977, s. 142-145.

43 Srov. Wendy Z. GOLDMAN, Women, the State and Revolution..., s. 207.

44 Tito besprizorniki byli obět'mi evakuací během druhé světové války a sociálních a ekonomických zvratů během revoluce 1917, krvavé občanské války a následné ekonomické krize. Strádající rodiče často opustili svoje děti v naději, že ony samy si někde najdou potravu, nebo $\mathrm{s}$ tím, že pokojně zemřou mimo jejich zraky. Mezi besprizorniky patřily také ilegitimní děti nebo děti z rozvrácených rodin. Rozvedené ženy často posílaly své děti žebrat na ulici. Více problematiku těchto dětí bez domova srov. Jennie A. STEVENS, Children of the Revolution: Soviet Russia's Homeless Children (Besprizorniki) in the 1920s, Russian History 9/1982, s. 242-264.

45 Srov. John HAZARD, The Child under Soviet Law, s. 430-431.

46 Srov. Nicholas S. TIMASHEFF, The Attempt to Abolish the Family in Russia, s. 145.

47 Carl J. FRIEDRICH - Zbigniew K. BRZEZINSKI, Totalitarian Dictatorship and Autocracy, New York: Praeger, 1965 , s. 92. 
se očekávalo, že budou udávat své rodiče.$^{48}$ Sovětští obyvatelé sami dosvědčovali, že v době třicátých let, kdy teror dosáhl vrcholu, bylo velmi nebezpečné diskutovat $\mathrm{v}$ rodinách o politických otázkách, protože mládež byla stranou neustále vybízena, aby udávala své nejbližší př́ibuzné. ${ }^{49} \mathrm{~V}$ sovětské literatuře byl za jednoho z největších hrdinů považován Pavlík Morozov. Morozovův př́iklad byl symbolem protikladu křestanské morálky („,cti otce svého a matku svou“) a komunistické morálky („,bud' bdělý a ostražitý"). Po celé období komunistického režimu byl oficiálně dáván za vzor dětem v Sovětském svazu i dětem v ostatních komunistických satelitech; jeho životopis od Vitalije Gubareva ${ }^{50}$ patřil mezi povinnou školní četbu. Př́ipadů, kdy se děti postavily proti rodičům, bylo nespočet.

Avšak také zákon z roku 1936 s sebou záhy přinesl důsledky, které komunističtí experimentátoři nepředvídali. Snadné dosažení rozvodu a legální potraty velmi snížily porodnost. Rozvolnění manželského svazku a oslabení vztahu mezi rodiči a dětmi vedlo k oslabení vztahů ve společnosti. Navíc se velmi zvýšila kriminalita mládeže. Komunisté docílili rozpadu institutu rodiny, jak zamýšleli, avšak daň za tento „úspěch“ byla př́liš vysoká. Národ se zdál být oslaben pro nadcházející válku. Vládě tedy nezbývalo nic jiného než přijmout taková opatření, která by pomohla zastavit tento neblahý vývoj. V rozporu s tím, co bylo hlásáno v předchozích letech, bylo nyní mladým lidem doporučováno, aby k institutu manželství přistupovali zodpovědně. Rodina se najednou stala důležitou součástí na cestě $\mathrm{k}$ dosažení komunismu.

\subsection{Druhá perioda: 1936-1944}

Nový zákon z roku 1936 měl změnit „lehkovážný postoj k rodině a rodinným povinnostem“. ${ }^{51}$ Oproti dosavadní legislativě znamenal doslova „šokující zvrat“ ${ }^{22}$ Zkušenost ukázala, že možnost rozvodu nevedla k osvobození žen, jak si to komunisté ve své teorii představovali. V novém zákoně z roku 1936 proto byla možnost se rozvést značně ztížena. Na úřad se museli dostavit oba manželé, kteři za rozloučení svého manželství museli platit: první rozvod 50 rublů, druhý rozvod 150 rublů a třetí rozvod 300 rublů. Také byla stanovena minimální částka, kterou musel muž platit na své dítě $\mathrm{v}$ př́ípadě rozvodu: třetina platu za jedno dítě, polovina platu za dvě děti a $60 \%$ platu za tři a více dětí. $V$ prŕípadě, že muž odmítl platit výživné na své děti, byl poslán na dva roky do vězení. ${ }^{53}$ Vzrůstající počet potratů a nízká porodnost vedly $\mathrm{k}$ tomu, že potraty byly zákonem opět zakázány. Pozitivní výsledky nového zákona se brzy dostavily. Již měsíc poté, kdy zákon vstoupil v platnost, se počet rozvodů v Moskvě snížil z 2214 na 215. Taktéž se výrazně snížila kriminalita mládeže..$^{54}$

Sovětská vláda si uvědomila, že její experiment vedoucí ke zrušení rodiny v duchu revolučních ideálů nevyšel. Právní teoretik Andrej Vyšinskij roku 1938 nazval právní teorie z dvacátých let "mimořádně nepromyšlenými zvrácenostmi“, které byly vytvořeny "skupinou pseudomarxistů", kteři "neváhali zanést naši právní literaturu pseudovědeckým odpadem“ ${ }^{55}$ Mnozí právní teoretikové, kteří se podíleli na přípravě starších zákonů majících zničit instituci rodiny, byli odstraněni.

48 „Na strážních věžích sovětské Ukrajiny stálo v létě 1933 půl milionu dospívajících chlapců a děvčat, kteří dostali za úkol sledovat dospělé. Od všech dětí se očekávalo, že budou donášet." Thomas SNYDER, Krvavé země: Evropa mezi Hitlerem a Stalinem, Praha-Litomyšl: Paseka; Praha: Prostor, 2013, s. 67.

49 Srov. Carl J. FRIEDRICH - Zbigniew K. BRZEZINSKI, Totalitarian Dictatorship and Autocracy, New York: Praeger, 1965 , s. 295.

50 Český překlad: Vitalij GUBAREV, Pavlík Morozov, Praha: Otakar II., 2000.

51 Michael D. BERGER, Soviet Divorce Laws and the Role of the Russian Family, Brigham Young University Law Review $3 / 1986$, s. 826.

52 Maurice HINDUS, House Without a Roof, New York: Doubleday, 1961, s. 139.

53 Srov. Wendy Z. GOLDMAN, Women, the State and Revolution..., s. 332.

54 Srov. Becky L. GLASS - Margaret K. STOLEE, Family Law in Soviet Russia, s. 899.

55 Srov. Wendy Z. GOLDMAN, Women, the State and Revolution..., s. 340. 
Nový zákon z roku 1944 se ještě více snažil posílit rodinu. Idealistická transformace mezilidských vztahů, která byla tak důležitá v porevolučních časech, musela nyní ustoupit ekonomickým zájmům. Během druhé světové války procházel Sovětský svaz velkou demografickou krizí. Ve válce padlo 27 miliónů vojáků a civilistů. V některých venkovských oblastech dosahoval poměr počtu mužů a žen v produktivním věku 19:100. Velké množství populace přišlo o své domovy v důsledku opakovaných masových mobilizací, evakuací a deportací. To vše mělo za důsledek, že se mnoho rodin rozpadlo. Navíc většina obyvatel trpěla podvýživou. Předsednictvo Nejvyššího Sovětu SSSR proto vydalo 8. července 1944 nařízení „o podpoře těhotných žen, matek s více dětmi a svobodných matek“. Vznikly čestné tituly a řády „Matka hrdinka“, „Mateřská sláva“ a "Medaile mateřství“. Pokud matka porodila tři a více dětí, byly jí vypláceny zvláštní bonusy. Reprodukce byla chápána jako občanská povinnost. Kdo nesplnil povinnou kvótu dvou dětí, musel zaplatit pokutu nebo jít do vězení. Od této povinnosti byli osvobozeni vojáci, studenti a osoby, které nemohly mít děti ze zdravotních důvodů. ${ }^{56}$

Manželé žádající o rozvod se museli dostavit před soud a zde vyložit své důvody, které mohly a nemusely být soudem shledány jako dostatečné. Zákon z roku 1944 dále zrušil institut „neregistrovaného manželství", který byl zaveden roku 1926. V právu se opět objevilo (kdysi buržoazní) rozlišení dětí na legitimní a nelegitimní. ${ }^{57}$ Ve snaze zvýšit počet sňatků byla obnovena možnost uzavřít sňatek v kostele, pokud manželství bylo uzavřeno i civilně. Svatební obřad se stal slavnostnější, v Leningradu a Kyjevě vznikly tzv. svatební paláce, které svou výzdobou měly poukázat na vážnost faktu uzavření manželství. Budoucí manželé měli k obřadu pozvat své přátele a příbuzné, aby byli svědky této nezapomenutelné události. Ve snaze ještě více posílit vazby mezi manžely se oproti minulosti zkomplikovala možnost rozvodu. Bylo zavedeno dvoustupňové soudní řízení. Manželé žádající o rozvod se museli dostavit k soudu, který se je snažil usmiŕit. Pokud se manželé neusmířili, museli se dostavit k soudu vyššího stupně, který po zdlouhavém slyšení a jednání rozvod bud' umožnil, nebo zamítl. Manželé museli svůj úmysl nechat se rozvést zveřejnit $\mathrm{v}$ tisku ještě před započetím soudních procedur. Poplatky související s rozvodovým řízením se také oproti předchozímu zákonu zvýšily. Již podání žádosti o rozvod stálo 100 rublů, rozvod samotný potom v rozmezí 600 až 2100 rublů. K posílení vztahů v rodině měl vést také zákon, který upravoval dědictví. Potomek mohl po svých rodičích zdědit majetek do výše 10000 rublů, ve zvláštních případech i více. Tento zákon, který upravoval problematiku dědictví a který po roce 1917 prošel změnami, byl nyní opět zaveden, aby byla zachována kontinuita v rodině a aby členové rodiny měli pro své dobré vztahy oporu v zákoně. ${ }^{58}$

\subsection{Třetí perioda: $1953-1964$}

Je třeba zmínit, že po Stalinově smrti v roce 1953 vedení strany upustilo od represivních metod, které byly v minulosti používány k ovládání populace. Chruščov po kritice kultu osobnosti navrhl nový model sociální kontroly, ve kterém režim bude více využívat kolektivní organizace, jako je Strana a Svaz mládeže. Každý kolektiv měl hledat ve svém středu narušitele společenského pořádku a mobilizovat proti nim. Strana se snažila, aby iniciativa přicházela odspodu, povzbuzovala své členy k disciplíně a vzájemnému sledování. ${ }^{59}$ Neustále bylo hlásáno, že každodenní život není soukromou záležitostí. Všichni členové kolektivu - at' už kolegové v práci

56 Srov. Mie NAKACHI, N. S. Khrushchev and the 1944 Soviet Family Law: Politics, Reproduction, and Language, East European Politics and Societies $1 / 2006$, s. 48-50.

57 Srov. Lauren KAMINSKI, Utopian Visions of Family Life in the Stalin-Era Soviet Union, Central European History 1/2011, s. 83-88.

58 Srov. Becky L. GLASS - Margaret K. STOLEE, Family Law in Soviet Russia, s. 899.

59 Srov. Edward D. COHN, Sex and the Married Communist: Family Troubles, Marital Infidelity, and Party Discipline in the Postwar Ussr, 1945-64, Russian Review 3/2009, s. 430-431. 
nebo sousedé - měli za úkol pomoci vychovávat ostatní členy kolektivu, dohlížet, aby vedli spořádaný osobní život, aby se stávali lepšími manželi a manželkami. Konkrétní případy, kdy různé organizace zasahovaly do manželských záležitostí, jsou důkazem toho, že komunistická morálka se úspěšně ujala. ${ }^{60}$

V padesátých letech definitivně vzaly za své utopické představy o tom, že by výchovu dětí mohl zcela převzít stát, a široce byl přijímán názor, že rodiče jsou ve výchově dětí nepostradatelní. Radikální názory o reorganizaci rodiny se sice ještě objevovaly, avšak nikdy se neujaly. Státní instituce již neměly za cíl nahradit rodiče, pouze jim měly ve výchově pomáhat. Aby si rodiče lépe uvědomovali společenský význam své role, sovětský pedagog a spisovatel Anton Makarenko sestavil podrobné materiály, které poskytovaly návody, jak ze svých dětí vychovat tvrdě pracující a uvědomělé komunisty. Makarenko vytvořil originální systém kolektivní výchovy, který byl uplatňován v Sovětském svazu a jeho satelitních státech. ${ }^{61}$ Makarenko byl přesvědčen o tom, že jeho pedagogika může vyřešit otázku výchovy detailní analýzou lidského jednání: „Prozkoumá mechaniku lidského úsilí, ukáže, jaké místo v něm patří vůli, ješitnosti, studu, vštěpování, napodobování, strachu a soutěžení a jak se to vše kombinuje s jevy ryzího uvědomění, přesvědčení a rozumu. . ${ }^{62}$

\section{4 Čtvrtá perioda: $1965-1980$}

V šedesátých letech se začala projevovat nespokojenost s př́liš složitou procedurou, kterou bylo třeba projít v případě rozvodu. Roku 1965 byla zrušena nutnost veřejně v tisku oznámit svůj úmysl se rozvést. Dvojstupňový soudní systém byl nahrazen regionálním lidovým soudem, od něhož bylo možno se dovolat k provinciálnímu soudu. Další změnou byl fakt, že svazky, v nichž se manželé vzájemně dohodli na rozvodu, mohly být rozvedeny také na registračních úřadech, kde byly uzavřeny (ZAGS). Musela však být dodržena tříměsíční lhůta od podání žádosti o rozvod po rozvod samotný. Rozvod soudní cestou mohl být teoreticky proveden v kratší době, nebot' zde nebyla žádná tříměsíční lhůta, avšak soud mohl žádat šestiměsíční lhůtu, ve které se manželé ještě měli možnost usmírit. Také poplatky se radikálně snížily. Pohybovaly se od 50 kopějek do 200 rublů. Jejich výše se odvíjela od toho, kolik manželé byli schopni zaplatit. Aby byly chráněny těhotné ženy a čerstvé matky, rozvod nebyl povolen během těhotenství ženy a rok po porodu dítěte. ${ }^{63}$ Jediným důvodem, který stačil k rozloučení manželství, byla nemožnost dalšího společného života nebo případ, kdy zachování rodiny „odporuje principů komunistické morálky“ ${ }^{64}$ Nejvyšší soud SSSR na svém plenárním zasedání v roce 1969 stanovil, že "občasné hádky nejsou platným důvodem pro rozvod“ ${ }^{65}$ Nejčastějším důvodem, který rozvádějící se partneři uváděli, byla závislost na alkoholu a nevěra. Platným důvodem k rozvodu byla také snaha jednoho z partnerů vychovávat své dítě v náboženské víře. Tomu z manželů, který s náboženskou výchovou nesouhlasil, mělo být umožněno, aby své děti vychovával na základě principů komunistické morálky. V roce 1980 nastal další obrat, který opět ztížil možnost rozvodu. Soud byl nucen zkoumat důvody vedou-

\footnotetext{
60 Srov. Deborah A. FIELD, Irreconcilable Differences: Divorce and Conceptions of Private Life in the Khrushchev Era, Russian Review 57/1998, s. 610-611.

61 Makarenko je jediným z raných sovětských experimentátorů ve výchově, jehož teorie přečkaly ideologické tlaky ve 30. letech. Základním výchovným prostředkem byl podle Makarenka kolektiv. Lidská individualita byla považována za překážku pro život v kolektivu. Jeho výchovný systém postrádal vnitřní logiku, avšak odpovídal tehdejším politickým potřebám, kterými bylo budování komunismu a sím spojená přeměna člověka. Srov. Bob CASKEY, The Pedagogical Theories of A. S. Makarenko: A Comparative Analysis, Comparative Education 3/1979, s. 277-286; Deborah A. FIEL, Private Life and Communist Morality in Khrushchev's Russia, s. 83.

62 Anton MAKARENKO, Pedagogická poéma, s. 449.

63 Srov. Michael D. BERGER, Soviet Divorce Laws and the Role of the Russian Family, Brigham Young University Law Review $3 / 1986$, s. 828.

64 Deborah A. FIELD, Irreconcilable Differences, s. 605.

65 Michael D. BERGER, Soviet Divorce Laws and the Role of the Russian Family, s. 829.
} 
cí k rozvodu. Mohl si také vyžádat svědectví organizací, ve kterých jsou manželé zapojeni, aby tak mohl lépe přispět k vzájemnému usmíření. ${ }^{66}$

\section{Závěr}

V této práci jsme se pokusili ukázat, jakou proměnou prošla rodina a vztahy mezi členy rodiny v období komunistického totalitarismu. Viděli jsme, že komunistický režim se hned od svého nástupu v Sovětském svazu snažil rozbít tradiční pojetí rodiny, tj. oslabit pouto mezi manžely navzájem a vztahy mezi rodiči a dětmi. Sledovali jsme dilema porevoluční sovětské vlády, která musela řešit pnutí mezi komunistickou sociální teorií a stabilitou společnosti. Ukázalo se, že sovětský experiment usilující o eliminaci rodiny ztroskotal. Ve dvacátých a třicátých letech dvacátého století se v sovětském „experimentu“ ukázalo, jak důležitou roli hraje rodina v prevenci kriminality. Sovětská legislativa oscilovala mezi zjednodušením rozvodových procedur z ideologických důvodů v letech 1936 a 1968 a znesnadněním rozvodu v letech 1944 a 1980. Jedním z nejdůležitějších komunistických hesel byla převýchova jedince v nového člověka, který bude uplatňovat novou morálku, jež je nutná pro přechod k ideálnímu komunismu. Člověk byl v tomto pojetí spíše loutkou pohybující se v mezích, které mu vytyčila strana. Není schopen vlastní iniciativy a za nic nenese osobní zodpovědnost. Pomocí totalitární ideologie se přemění v součást masy, pro kterou je velmi snadné podlehnout propagandě. ${ }^{67}$ Hlavní výchovnou metodou byla kolektivní výchova, která se snažila co nejvíce potlačit přirozenou spontaneitu jedince. Stát se snažil co možná nejvíce převzít roli rodiny, takže vznikla různá společná zařízení, ve kterých jedinec trávil (byl nucen trávit) více času než ve vlastní rodině. I přes všechny snahy státu dohlížet co nejvíce na výchovu jedinců se však ukázalo, že institut rodiny je nutný pro stabilitu každé společnosti.

\section{Charakteristika rodiny a (pře)výchovy v komunistické perspektivě}

Abstrakł Článek se pokouší charakterizovat proměnu chápání instituce rodiny a mezilidských vztahů v komunistické ideologii. Nejprve jsou představeny základní cíle komunismu - vyłvoření "nové morálky", která již nespočívá na náboženských nebo tradičních hodnotách, a "nového člověka", který svou přirozenost získává teprve vztahem ke společnosti. Nové pojetí člověka se nutně promítlo do chápání rodiny a vztahů mezi manžely a mezi rodiči a dětmi. $\vee$ článku jsou zmíněny čtyři základní periody, ve kterých se vyvijelo chápání rodiny v Sovětském svazu. Rodina byla nejprve považována za buržoazní přežitek, a tudíz odsouzena k zániku. Postupně se však ukázalo, že rodina představuje základní instituci, bez které se neobejde žádné politické uspořádání. Komunistický režim se tak alespoň snažil co nejvíce zasahovat do soukromí jedince v celém průběhu jeho života.

Klíčová slova rodina, manželství, komunismus, nový člověk, ideologie, marxismus-leninismus, mezilidské vztahy

\section{The Characteristic of Family and (Re-)Education in the Communist Perspective}

Abstract The paper tries to characterize the transformation of conceiving the institution of family and interpersonal relationships in communist ideology. First the basic goals of communism are presented -

66 Srov. Michael D. BERGER, Soviet Divorce Laws and the Role of the Russian Family, s. 831.

67 Velmi trefně píše Hannah Arendtová: „Cílem totalitní výchovy nikdy nebylo vštěpovat přesvědčení, ale zničit schopnost si nějaké utvořit.“ Hannah ARENDTOVÁ, Pน̊vod totalitarismu, Praha: OIKOYMENH, 2013, s. 631. 


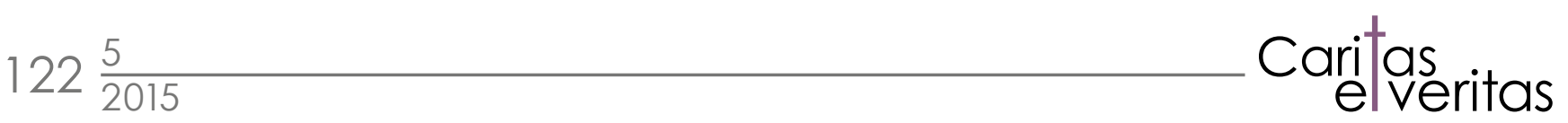

creating a "new morality" which no longer rests on religious or traditional values and a "new human" who obtains her nature only by relationship to society. The new conception of human being was necessarily projected into the conception of family and relationships between spouses and between parents and children. The paper mentions four basic periods in which the conception of family in the Soviet Union developed. The family was first regarded as bourgeois residue and therefore condemned to extinction. But it gradually turned out that the family is a fundamental institution without which no political order can get by. So the communist regime at least tried to intervene in the privacy of individuals as far as possible throughout their lives.

Keywords family, marriage, communism, new human, ideology, Marxism-Leninism, interpersonal relationships 